\title{
Wealth and Stratification Processes
}

\author{
Seymour Spilerman \\ Department of Sociology, Columbia University, New York, NY 10027; \\ e-mail:ss50@Columbia.edu
}

\begin{abstract}
Key Words intergenerational transfers, inequality, living standards
abstract This paper reviews current information on wealth trends, with particular attention to the role of household wealth in the stratification system. The first section considers the relevance of wealth for stratification processes and examines why an appreciation of household wealth has been slow to materialize in stratification research. Subsequent sections discuss aspects of the distribution of household wealth in the United States, the transmission of inequality across generations, and implications of a consideration of wealth for stratification theory and social policy. The concluding section conveys some observations about the need for developing models of consumption potential and living standards, akin to the socioeconomic attainment formulation, which incorporate measures of household wealth and the transmission of wealth.
\end{abstract}

\section{INTRODUCTION}

American stratification research has been characterized by an almost exclusive focus on labor market processes and rewards, to the neglect of a consideration of wealth and unearned income. This has meant adoption of the individual as the unit of analysis since the individual is the actor in the labor market, rather than the family, though most theoretical writings have emphasized the latter as the appropriate unit in a stratification system (Barber 1975, p. 75; Parkin 1971, pp. 14-15). In the socioeconomic attainment paradigm this discrepancy was often finessed by arguing that family status is derivative of head's occupational status and that family income can be approximated by head's labor market earnings (e.g. Jencks 1979, p. 9; Rosenfeld \& Kalleberg 1990, pp. 80-82).

This focus on achievement has meant a preoccupation with the production of labor market rewards (occupational status and earnings). The influential socioeconomic attainment model (Blau \& Duncan 1967; Jencks et al 1972), for example, can be thought of as specifying a transformation of education and other background variables into a status trajectory or an earnings stream. An alternative theoretical formulation, less developed in stratification research, would focus on consumption potential, essentially the capacity of a family to maintain a particular standard of living. Such a formulation would be better suited to examining questions of living 
standards, economic security, and poverty, which reflect a family's total resource base, not just its income from labor market activity.

Definitions of social class have also been firmly anchored in the sphere of production (Giddens 1973, p. 80; Blau \& Duncan 1967, p. 5), to the extent that Saunders (1984) has objected to the use of the term "class" in connection with consumption processes, though he had earlier contributed to the development of this very literature (Saunders 1978). ${ }^{1}$ It is also the case that Weber (1958, pp. 18095 ), in his influential delineation of stratification systems, locates consumption on the status dimension of his typology. However, the referent in Weber's discussion is to "lifestyle"-i.e. consumption pattern-not to level of consumption or consumption potential. The latter themes, I suggest, are more rooted in economic calculations than in status concerns.

Why, then, this almost exclusive concentration on labor market processes and the neglect of wealth and unearned income in stratification research? In part, this proclivity can be attributed to the theoretical formulations that have guided empirical studies. A dismissal of private property (possessions) and inheritance is implicit in the functionalist theory of stratification, since the role of these factors is anomalous in a conceptual system that stresses the contributions of merit and skill to the social order (Davis \& Moore 1945; Parkin 1978, p. 610). Also, in Marxian theory, it is one's position in the productive system that underlies life chances and living standards. Neo-Marxian authors have expanded the traditional Marxian formulation by considering the unique situations of different occupational groups, yet location in the productive order remains the essential explanatory dynamic (e.g. Wright \& Perrone 1977; Wright 1985; Poulantzas 1975; see Parkin 1978, pp. 613-16 for a review).

There is also an empirical basis to the neglect of wealth in stratification research since occupational rewards are clearly the principal determinant of living standards in a modern industrial country. "Because property ownership is so heavily concentrated in the hands of so few, it does not figure as the primary source of reward for the mass of the population" (Parkin 1971, p. 24). Parkin continues by noting that the long-run tendency in Western countries has been for the share of family income deriving from property to diminish, relative to income from employment (p. 24). Calculations from Internal Revenue Service data of the proportion of family income that can be attributed to wages, salary, and entrepreneurial activity are

\footnotetext{
${ }^{1}$ Saunders (1978), along with others, formulated the concept of housing class, in recognition of the opportunity provided by home ownership for wealth accumulation as well as the particular economic interests generated by home ownership. In a subsequent paper, Saunders (1984) rejected the use of the term "class" in connection with housing or the consumption sector, while continuing to emphasize the importance of consumption cleavages as a fault line in Western society. In an earlier literature, Lipset \& Zetterberg (1956, p. 158) did use the term consumption class, but in conformity with the Weberian specification of status group: "It is the way income is spent, rather than the total amount, that determines a man's consumption class." In contrast, in this essay, the term consumption potential is used to refer to the totality of a family's economic resources.
} 
in the vicinity of $84 \%$ (Lenski 1984, p. 188), though there are variant estimates (e.g. Jencks et al 1972, p. 212; Rainwater et al 1986, p. 40; Slemrod 1991).

Yet, despite the centrality of labor market attainment to economic well-being, I argue in the next section that the presence of household wealth is much more consequential to a family's living standard than can be conveyed by a simple calculation of the share it contributes to family income. Moreover, there has been a substantial decline in wealth concentration in the American population, a trend that began early in the twentieth century. As a result of the consequent wealth dispersion, considerations of family asset holdings have become increasingly relevant to general stratification analysis, aside from their long-established salience in elite studies (e.g. Mills 1956, Kolko 1962).

From a stratification perspective, a derivative consideration to addressing the contributions of household wealth concerns the role played by family assets in the replication of inequality across generations. Empirical research has long taken as one of its central themes a clarification of the opportunity structure for young persons - essentially a determination of the prospects for upward mobility starting from father's location (e.g. Blau \& Duncan 1967; Jencks et al 1972). To the extent that this question is framed in the context of labor market prospects, the principal policy issues relate to the effectiveness of educational institutions in facilitating occupational attainment. However, to the degree that stratification outcomes are framed in terms of consumption potential-living standards and economic wellbeing - the analysis must also encompass considerations of wealth and the means for acquiring wealth, whether through parental transfers or life-cycle accumulation.

In this review I examine the role of household wealth in the stratification system. ${ }^{2}$ In the next section I discuss the relevance of wealth and convey some reasons why an appreciation of wealth processes has been slow to materialize in stratification research. Subsequent sections discuss aspects of the distribution of household wealth in the United States, the transmission of inequality across generations, and implications of a consideration of wealth for stratification theory and social policy. I conclude with some observations about the need for developing models of consumption potential and living standards - akin to the socioeconomic attainment formulation - which incorporate measures of wealth and the transmission of wealth.

\section{THE IMPORTANCE OF HOUSEHOLD WEALTH}

Attention has long been given to the privileges and life styles that derive from wealth (e.g. Baltzell 1958; Mills 1956; Kolko 1962); this body of work is a recognized specialty in sociology and economics — the field of "elite studies." As the

\footnotetext{
${ }^{2} \mathrm{~A}$ related issue concerns the impact of public transfer programs on living standards. Because these programs are diverse and targeted to particular qualifying populations (e.g. the poor, the elderly), I do not address governmental transfer programs in the present review.
} 
name suggests, investigations into the sources and benefits of household wealth were traditionally limited to appraisals of the circumstance of very rich families. Indeed, until perhaps a decade ago, little consideration was given to how the possession of modest financial resources might influence economic well-being in the wider American population.

The lack of acknowledgment of wealth holdings in assessments of the living standard of the average family began to change in the 1980s. I would cite three factors as particularly responsible: $(a)$ an emergent appreciation of the contributions of family wealth - even modest financial resources - to living standards; (b) the rapid equity buildup in the American population since World War II; and (c) the growing availability of wealth data at the level of the family or household unit.

\section{Attractiveness of Wealth}

By the term wealth I refer to a family's liquid financial assets (stocks, bonds, savings accounts) and its real property, such as a home. If income is depicted as a "flow" (with units of dollars/time), then wealth can be viewed as a "stock," a potential for an income flow. Following this imagery, one approach to establishing comparability between wealth and income is to view the former as a capitalized income stream. That is, an annuity can be purchased that will provide the asset holder with a certain lifetime income. By means of this transformation, wealth can be compared with the income flow generated by labor market activity.

However, wealth has several attractive features that are not shared by earnings (Sherraden 1991, chap. 8; Spilerman et al 1993, p. 169): (a) The income generated by wealth does not require a tradeoff between leisure and work - there is no cost in the form of foregone alternative use of time. $(b)$ Unlike labor market earnings, the income flow generated by wealth does not decline with illness or unemployment. (c) Wealth can be enjoyed without being consumed, such as when held in the form of a fine painting or a dwelling. $(d)$ Tax law treats wealth appreciation more favorably than labor market income. (Currently, the maximum tax rate for earned income is $39.6 \%$ versus $20 \%$ for capital gains.) (e) In time of economic crisis the wealth principal can be consumed-which is hardly the case with human capital.

The last point has particular relevance for low income families. Even modest levels of financial assets, which normally provide only a small addition to total income, can cushion a family from the economic shock of illness or job loss, enabling a home mortgage, car loan, and other bills to be paid for a number of months and thereby preventing a temporary loss of employment from snowballing into a wider crisis for the family. Households with few financial assets, especially African-American families (Oliver \& Shapiro 1995; Conley 1999), are particularly vulnerable to such economic dislocations.

Whether a family's income derives principally from work effort or from asset holdings will influence its consumption behavior. Wealth reduces the need to 
accumulate savings, which an individual lacking financial assets must do in order to build a security cushion or in anticipation of retirement. Sizable household wealth obviates the need to purchase life insurance, freeing funds for other uses. Thus, with family income held constant, the extent to which the income flow stems from wealth, rather than from labor market activity, will affect the allocation between consumption and savings (Danziger et al 1991). Even the anticipation of future wealth, such as the expectation of an inheritance, may influence the allocation, in that the expected availability of assets would be factored into a family's calculation of its need to save (Weil 1994).

\section{Buildup of Wealth in the American Population}

The above comments provide a rationale for giving consideration to family wealth as a potentially significant factor in living standards. Yet, to the extent that household wealth remains concentrated in the hands of a few, the preceding argument would carry little import for general stratification processes, as distinct from elite studies.

It is therefore crucial to observe that in addition to the buildup in average family wealth, there has been a pronounced trend toward wealth dispersion in Western countries (Shorrocks 1987; Spant 1987); details are presented in a later section. While the average family may have accumulated only modest assets in an investment portfolio or in a savings account, home equity and pension equity have grown by substantial amounts (Wolff 1995; Ratcliff \& Maurer 1995; see Shorrocks 1987 for similar findings for Great Britain). These forms of wealth holdings are more widely distributed in the population than are investment assets, and their growth is responsible for much of the noted decline in wealth concentration.

\section{Availability of Data on Asset Holdings}

I would suggest that the single most responsible factor for the growing attention to family wealth and to the impact of family assets on living standards is the recent availability, from several large surveys, of asset data at the household level. The first survey of a large representative sample that inquired about asset holdings was the 1962 Survey of Financial Characteristics of Consumers (Projector \& Weiss 1966). While their findings concerning the composition and distribution of household wealth were quoted widely, no significant follow-up study of wealth holdings was conducted until 1983, at which point the Survey of Consumer Finances (SCF) and the Survey of Income and Program Participation (SIPP) entered the field with detailed sections on household assets. In the following year, the Panel Study of Income Dynamics (PSID), an ongoing survey since 1968 of the characteristics of American households, added a module on family wealth.

Because the 20-year hiatus in data collection was a period rich in social surveys on related topics, such as labor market behavior and family income, one can only surmise that household wealth information was not considered important enough 
to warrant an investment of time and money in its gathering. ${ }^{3} \mathrm{I}$ am not sure there was a triggering event which suddently produced three quality surveys in 19831984. More likely, it was a confluence of the first two of the three considerations enumerated above; collectively, a realization that the contribution of household wealth to living standards could no longer be ignored. But whatever the instigating factor, the availability of micro-level data on asset holdings has, in turn, stimulated much activity aimed at discerning the particular ways by which financial resources contribute to well-being, prompting a concern with definitions of wealth and categorization of types of assets (e.g. Smith 1995; Wolff 1995; Sherraden 1991, chap. 6), as well as a new round of data collection, this time more focused on substantive themes such as wealth transfers and particular target populations, especially the elderly [e.g. Survey of Assets and Health Dynamics among the Oldest Old (AHEAD); The Health and Retirement Study (HRS)].

\section{THE MEASUREMENT OF HOUSEHOLD WEALTH}

Wealth is commonly identified with net worth and assessed by survey questions that measure the total value of family assets and the amount of debt, and that equate net worth with the difference between the two quantities. However, there are various categories of household assets, with different features, and if the wealth variable is to be used to explain individual or household behavior, it can be important to distinguish among the wealth components.

Wolff (1995; 1996, pp. 75-84) differentiates among marketable wealth, financial wealth, and augmented wealth. He equates marketable wealth with net worth, though his measure excludes some assets that are usually included in a net worth measure-consumer durables such as an automobile, television, and household appliances. This is done on the grounds that these items have less resale value than their consumption services to the household and, presumably, would not be marketed to free up funds. A criticism of the exclusion is that it distorts the net worth of poor households because consumption durables, especially an automobile, account for the bulk of asset holdings by these families (Current Population Reports 1986, Tables 1, 3).

Financial wealth is defined by Wolff as marketable wealth minus equity in owner-occupied housing. It is intended as a measure of "liquid" resources, since a home is difficult to convert into cash in the short term. Financial wealth therefore reflects the resources immediately available for consumption (Wolff 1995, p. 36). Augmented wealth adds to marketable wealth some items not customarily included

\footnotetext{
${ }^{3}$ Notwithstanding the absence of surveys, research on wealth issues continued during the 1960s and 1970s, often addressing macro-level questions and relying on estimates of the wealth distribution from filings of estate tax returns (e.g. Menchik 1979; Wolff 1980). Indeed, the main professional society on the subject of wealth, the International Association for Research on Income and Wealth, was founded more than 50 years ago, in 1947.
} 
in a net worth measure-principally pension wealth and Social Security wealth, the latter calculated as the discounted present value of the Social Security retirement benefit.

Burkhauser \& Weathers (2000) employ a similar but more detailed decomposition of household wealth, using the categories financial wealth, housing equity, Social Security wealth, and employer pension wealth. They examined the wealth holdings of a mature population, the age cohort 51-61. With this population divided into deciles of total wealth, they report that in the lowest deciles the principal asset is Social Security wealth, in the middle deciles housing wealth comprises a major proportion of total wealth, and in the highest deciles financial wealth is the dominant component.

Yet, in all but the very highest decile, Social Security wealth and pension wealth comprise at least $50 \%$ of total household wealth in this middle-aged cohort (Burkhauser \& Weathers 2000). This raises a question of whether it is appropriate to include these asset types in the wealth measure, a determination that is especially consequential since they would dominate the wealth estimate. Calculations of household wealth or net worth typically exclude retirement assets (e.g. Oliver \& Shapiro 1995, p. 58; Current Population Reports 1986, p. 1). A more general phrasing of the question would inquire how wealth should, in fact, be measured if the intent is to assess its impact on some behavioral outcome.

Three considerations would appear to be relevant: $(a)$ the formulation of the household resource measure, $(b)$ the features of different kinds of assets, and (c) the salience of the prospective wealth components to the behavioral outcome under investigation.

(a) The first issue relates to whether income and wealth are retained as distinct concepts or merged into a single resource variable. As an example of the latter, in a discussion of family vulnerability to a financial crisis, Wolff (1990) created a single measure of economic resources by annuitizing the wealth stock and adding the result to household income. When this approach is taken, it matters little whether a particular household asset is viewed as an income flow or as a wealth component.

If the distinction between income and wealth is maintained [e.g. Conley (1999) in an analysis of racial disparities; Conley \& Spilerman (2000) concerning wealth effects on educational outcomes], the question of asset classification becomes relevant. For example, by capitalizing Social Security income and converting it into a wealth stock, this asset is moved from one resource category to the other. Clearly, the respective effects of income and wealth on a behavioral outcome will be sensitive to this manipulation.

(b) The second issue concerns the features of a resource item. As noted earlier, Wolff (1996) emphasized the dimension of marketability as a basis for differentiating among wealth components. An alternative categorization would stress the degree of control over the asset by its owner (Sherraden 1991, chap. 6). For example, the withdrawal of money from an IRA account is subject to IRS regulations. Access to pension funds held by an employer can be even more restricted, since 
these monies are intended for distribution as an income stream upon retirement. Thus, while we can formally proceed by adding pension assets to a household's net worth, access to the funds, especially to the pension principal, can be severely limited.

In discussing pension assets it is important to distinguish between a defined contribution and a defined benefit plan. In the case of the former, a wealth principal is present in the name of the asset holder; however, in a defined benefit plan-e.g. Social Security benefits - there is no underlying principal that can be withdrawn or inherited, only the promise of an income stream during the asset owner's lifetime. While one can capitalize the income flow and speak of "Social Security wealth," the same can be done with any income stream, including labor market income. In short, if the distinction between income and wealth is to be maintained, it does not seem appropriate to include the capitalized value of a defined benefit plan as a component of household wealth.

(c) The third issue is of a different sort, referring to the definition of the wealth variable in the context of the behavioral outcome under investigation. This sort of issue is not addressed when the resource variable is household income, because income is fungible and rarely carries use restrictions that relate to its source. ${ }^{4}$ However, the features of a household's wealth components can differ in terms of marketability and control over the principal. As a consequence, one cannot assume that a measure of total household wealth is necessarily the appropriate wealth variable for use in examining a particular behavior. In a study of endstate bequests, for example, it would make little sense to include the capitalized value of Social Security income as a parental wealth component since this asset cannot be transferred.

On a similar note, if one seeks to explain parental financial assistance with a child's education, it is not evident that the value of the parental home should be included in the wealth measure, versus using a calculation of "liquid" wealth. In general, when it is unclear how to formulate the wealth variable, when it is not evident to which wealth components an individual would be responding, it is recommended that an analysis be made of the "sensitivity" of the behavioral outcome to alternative specifications of the wealth variable.

\section{THE WEALTH HOLDINGS OF AMERICAN FAMILIES}

\section{Trends in Household Wealth}

As noted, the first large scale survey of household wealth was carried out in 1962 (Projector \& Weiss 1966). Nonetheless, estimates of wealth holdings have

\footnotetext{
${ }^{4}$ Food stamps issued to the poor provide an exception, since their use is restricted to certain kinds of purchases.
} 
been available for many prior years, dating back to the early decades of the twentieth century. These early estimates are based on aggregate household balance sheet accounts (macro data) and on estate tax returns filed on behalf of the deceased.

Wolff (1989) presents four time series of wealth estimates which differ in their treatment of trust fund holdings and retirement assets. Using the narrowest definition of wealth — essentially a measure of net worth-Wolff reports an increase from $\$ 5,300$ in 1921 to $\$ 13,400$ in 1983 (1967 dollars); with retirement assets added, the change is from $\$ 5,400$ to $\$ 23,220$. These figures refer to mean per capita wealth (not to the more customary household estimates), and reveal a strong trend toward wealth accumulation in the American population over the referenced period. The growth in home equity and pension assets is responsible for much of the wealth increase: The former, as a proportion of total wealth holdings, rose from $10 \%$ to approximately $20 \%$ during this period; the latter expanded from $2 \%$ to $42 \%$ [calculated from Wolff (1989, pp. 20, 24)].

More recent computations cover the period 1962-1995 and report wealth estimates based on survey data. With the household as the unit of analysis, and excluding retirement assets, Mishel et al $(1999$, p. 264) find an increase in mean net worth from $\$ 143,000$ to $\$ 215,000$ (1997 dollars). Because the estimates are from micro data it is possible to also calculate medians, which are more informative about the living standard of the average household. These are much lower than the mean figures, ranging from $\$ 35,200$ in 1962 to $\$ 45,600$ in 1995 (1997 dollars). The enormous disparity between the median and mean figures attests to the considerable skewness in the wealth distribution.

Wealth Inequality Calculations from estate tax returns indicate a substantial decline in wealth concentration during the twentieth century. According to the Lampman-Smith-Schwartz time series (Committee on Ways and Means 1992, p. 1564), the richest $1 \%$ of the population owned $36 \%$ of household net worth in 1929; by 1982 the figure had dropped to $20 \%$. Wolff (1996, pp. 75-86) refined this time series, distinguishing between net worth and "augmented wealth": In the latter, pension and Social Security assets have been added to net worth. Not surprisingly, the decline in wealth concentration is more steep under the second measure, since retirement assets have grown rapidly and are more widely dispersed than other wealth components, especially investment assets. The spread of home ownership, which grew from $44 \%$ to $65 \%$ between 1940 and 1995, has also contributed to the reduction in wealth concentration (Wolff 1987, p. 241).

It appears, however, that since the early 1980s there has been a sharp reversal in the trend to lesser wealth inequality. Wolff (2000) reports a $2 \%$ decline in median wealth between 1983 and 1997, along with a 14\% increase in mean wealth. The divergence of these two statistics suggests a growing polarization in wealth holdings and, consequently, greater inequality in 1997; this assessment is supported by calculations of the proportion of household net worth held by the richest $1 \%$ of 
the population, which grew from $34 \%$ to $40 \%$ in the noted 15 -year interval (Wolff 2000). ${ }^{5}$

Another way to look at shifts in the distribution of household wealth is to examine the change for different wealth deciles. Compilations by Wolff (2000) reveal that between 1983 and 1995 the wealthiest $1 \%$ of households experienced a $17 \%$ growth in net worth, the next wealthiest $4 \%$ saw their net worth increase by $0.5 \%$, and the remaining $95 \%$ of the population witnessed a decline in net worth, the loss being greater for the poorer households. Also telling, during this period the proportion of households with zero or negative net worth increased from 15.5\% to $18.5 \%$ (Mishel et al 1999, p. 259). In summary, the evidence is compelling that after several decades of declining wealth inequality, there has been a renewed trend to wealth concentration and greater inequality.

Components of Wealth A principal factor in the wealth buildup among the very rich is the concentration of their resources in business equity and investment assets-stocks, bonds, commercial real estate-which have appreciated rapidly in the past decade (Mishel et al 1999, pp. 266-74). Indeed, there is a striking difference in the composition of asset holdings among families at different net worth deciles. Thus, in 1995, a principal residence accounted for $73 \%$ of net worth in the $40 \%$ of families with lowest household wealth, but only $6 \%$ of net worth in the richest $1 \%$. In contrast, the wealthiest $1 \%$ of households held $78 \%$ of their net worth in the form of business and investment assets (Wolff 2000).

Wolff does not provide details on asset holdings by wealth level for the poorer half of the population. However, some insight can be gleaned from earlier studies. In Current Population Reports (1986, pp. 9-15) calculations are presented for the incidence of asset ownership and for the mean value of an asset, conditional on ownership. With respect to a principal residence, the data indicate a low ownership rate among poor households ${ }^{6}(10.5 \%$ versus a population mean of $64 \%)$, but in regard to an automobile, the rate of ownership by the poor is relatively high $(64.5 \%$ versus a population mean of $86 \%$ ). These data do not permit a simple calculation of the proportion of household wealth that is accounted for by particular asset types, but they do suggest that a large proportion of the resources of the poor is tied up in automobile equity.

The earlier survey by Projector \& Weiss (1966, p. 110) permits a clearer assessment. Among middle wealth households (the $58 \%$ of families with net worth in the

\footnotetext{
${ }^{5}$ Wolff's time series of net worth concentration shows a turning point in 1976, whereas the Lampman-Smith-Schwartz series does not exhibit a termination to the decline in wealth inequality even as late as 1982, the final year of this series. According to Wolff (1996, pp. 78-79) the proportion of wealth owned by the richest $1 \%$ of households was $20 \%$ in 1976 and $31 \%$ in 1983. Wolff (2000), in his comparison with 1997 data, reports a concentration figure of $34 \%$ for 1983 .

${ }^{6}$ Poor households are defined here as the approximately $25 \%$ of families with net worth below \$5,000 in 1984.
} 
range $\$ 1,000$ to $\$ 25,000$ in 1962), some $54 \%$ of total net worth was accounted for by home ownership and $9.5 \%$ was tied up in automobile equity; among the $24 \%$ of households with wealth holdings below $\$ 1,000,10 \%$ of net worth was associated with home ownership and $48 \%$ was held in the form of an automobile.

The significance of this asset-holding pattern is that home residences, which account for the bulk of net worth among households in the middle wealth range, have tended to appreciate in value over time; moreover, mortgage interest payments and capital gains from the sale of a primary residence are treated favorably in tax law. In contrast, automobile equity - the form of asset holding most common among poor families-depreciates rapidly in value. This is not to suggest that poor persons make faulty decisions with regard to the selection of assets. An automobile can be critical for getting to a place of work and could even be a job requirement; moreover, the purchase of a home may necessitate a down payment, which might not be within the reach of a poor household. The point to be emphasized is that poor families are constrained in their asset allocation decisions, and there are strong imperatives for purchasing the sorts of assets that do not result in wealth appreciation.

\section{Distributional Features of Wealth Holdings}

Household wealth increases with education and age, and is much lower for AfricanAmerican and Hispanic households than for white families (Committee on Ways and Means 1992, p. 1573). The education effect captures the greater opportunity for life-cycle accumulation by highly educated and therefore high income families, though it also taps the likelihood of coming from a parental home with some assets and receiving parental transfers, unless these factors have been controlled.

Regarding the age effect, cross-sectional data reveal a pattern of wealth accumulation through the mid-60s, followed by a subsequent decline in wealth holdings. While this pattern is consistent with the life-cycle explanation of household wealth (Osberg 1984, p. 196) - accumulation during the years of maximum earnings, followed by a spending down of assets - the decline is also consistent with a cohort explanation in which there is no spending down but a history of lower rates of accumulation by the earlier cohorts. Indeed, from studies based on longitudinal data, Shorrocks (1987) and Alessie et al (1997) concluded that a sizable fraction of households do not dissave in old age. This suggests that the age-wealth profiles from cross-sectional data should be interpreted descriptively and not used to infer life-cycle behavior.

There have also been troublesome changes in the age distribution of wealth holdings, essentially a decline in the wealth level of young cohorts, relative to the wealth base of older households. Levy \& Mishel (1991, p. 53) documented this tendency for the period 1977-1983; Wolff (2000), reviewing recent data, finds a continuation of the trend during 1983-1995. These findings are probably responsible for a second trend - the decline in home ownership rates among young families. While the overall rate of home ownership grew between 1983 and 1995, reaching $64.7 \%$ in the latter year, the rate declined for families in their 40 s or younger (Wolff 
2000). Levy \& Mishel (1991, pp. 68-69) reported similar findings for the earlier time period, and noted an especially pronounced fall in young households with low education. In summary, there is evidence of a growing liquidity constraint among young cohorts, compelling a delay in home purchase. This, in turn, will deprive young couples of several years' participation in the wealth buildup that frequently derives from home ownership.

The racial disparity in wealth holdings is immense. According to Current Population Reports (1986, p. 19), median net worth in 1984 was $\$ 39,135$ for a white household and \$3,397 for an African-American household. Results from a followup survey four years later reveal a slight improvement in the ratio of AfricanAmerican to white net worth-a decline from the 10:1 ratio in 1984 to 8:1 in 1988 (Committee on Ways and Means 1992, p. 1577). More recent estimates by Wolff (2000) for 1995 show white median net worth at $\$ 61,000$ versus $\$ 7,400$ for African-American households, which maintains the 8:1 ratio. The disparity is only partially explained by racial differences in income or marital status, in that the wealth gap remains huge even within categories of these variables (Current Population Reports 1986, p. 5).

Further insight into the racial wealth gap emerges from an examination of how the gap varies by age, and from a consideration of alternative wealth measures. Wolff $(1994$, p. 166) reports the ratio of nonwhite to white mean net worth for different age cohorts, showing a decline from .58 to .14 as one moves to the older age groups. In short, white families are either more successful in saving from their incomes, accumulating assets over time, or, more likely, they receive larger inheritances from parents, an assessment supported by transfer data in Smith (1995, p. S175) based on the 1992 Health and Retirement Study. In the same paper, Smith shows that if the net worth measure of wealth is augmented by adding to it the capitalized value of Social Security benefits, the wealth gap between the races is much reduced since Social Security transfers are redistributive in character.

There have been two noteworthy attempts to tease out the implications of lower asset holdings by African-Americans. Oliver \& Shapiro (1995) first document the impact on living standards and economic opportunity, such as depressed rates of home ownership and business entrepreneurship, since some resources are necessary for establishing credit-worthiness to secure a mortgage or a business loan. They then consider strategies to assist poor households. These involve programs to foster asset accumulation and promote what Sherraden (1991) has termed a "stakeholder's society." Essentially, private groups or government agencies would encourage the establishment of individual savings accounts that could be used only for targeted purposes - to further one's education or for investment in a business or a residence. The accounts would be subsidized for poor families, either through matching deposits or by a refundable tax credit. Conley (1999) makes similar policy recommendations, again emphasizing the importance of property ownership and wealth accumulation for the welfare of African-American families. 


\section{The Effects of Wealth}

In contrast to the considerable literature documenting trends in asset holdings and inequality, few studies have attempted to formally assess the impact of household wealth, net of income, on aspects of living standards. Rather, the causal argument as to the importance of wealth is usually verbal, involving an appeal to common knowledge about the mechanisms underlying attainment in a particular institutional area, such as home ownership, sometimes coupled with the presentation of crosssectional data showing an association between wealth and the attainment variable of interest. However, the direction of causality is often ambiguous in cross-sectional data-for example, are current homeowners more wealthy than renters because of an increase in home values, or were they able to purchase because of greater wealth at an earlier time point?

One area in which causality is not an issue concerns the effects of parental wealth on the living standards of adult children. This literature is reviewed in the next section. Here, I limit my comments to wealth effects on current asset holders. These have been documented in regard to labor market participation and expenditure behavior, especially for large-ticket items that cannot be readily financed from an income flow. Thus, Semyonov et al (1996), using Israeli data, find wealth effects on the standard of living as reflected in the ownership of household appliances. The impact is stronger for European-origin Israelis, who have greater net worth, than for Israelis from Asian or North African lands; possibly these effects occur only above some threshold level of wealth holdings. Wealth effects have also been reported for wife's labor force participation [a decline with net worth (Theeuwes 1981)], for self-employment prospects [enhanced by household wealth (Lindh \& Ohlsson 1998)], and for the likelihood that an elderly homeowner will move to smaller quarters [lower for wealthier families (Feinstein \& McFadden 1987)].

A different kind of wealth effect, one in which household net worth is viewed as a reserve, may be more consequential for assessing living standards and economic security. In particular, Wolff (2000) examines the protective effects provided by wealth, calculating the number of months that current consumption can be sustained by families in different income quintiles. On average, households in the top quintile have sufficient net worth for 16.5 months; in the next to lowest quintile the wealth holdings can sustain a family for 0.9 months, and in the lowest there is no wealth reserve, hence, great vulnerability to illness or loss of employment. Wolff's calculation is little more than an accounting device, a restandardization of the wealth values, yet the protections from economic dislocation conveyed by his figures are very real.

\section{A Note on the Wealth Figures}

Estimates of household wealth are much less consistent over representative surveys than is the case with income estimates. This is true even when household wealth is measured by putatively the same statistic, such as net worth. The differences among 
estimates arise from several factors: $(a)$ the complexity of wealth surveys, which must assess an array of wealth components-stocks, bonds, savings accounts, a principal residence, other real estate, business equity, life insurance equity, and consumer durables; $(b)$ the lack of standardization in questions used for inquiring about the wealth components; $(c)$ the difficulty that respondents have in estimating the value of some components; and $(d)$ the high rate of refusal in responding to asset items. The last has given rise to a small industry on strategies for imputing missing data; see Smith (1995) for a review of the various techniques.

There are, however, disparities in estimates. According to Wolff (2000), median net worth is uniformly higher in SCF estimates (Survey of Consumer Finances) than in either SIPP (Survey of Income and Program Participation) or in PSID (Panel Study of Income Dynamics). In 1988-1989, for example, median net worth was estimated as \$46,100 in SIPP, \$45,200 in PSID, but \$62,400 in SCF. Mean net worth for the same years shows an even greater range: $\$ 118,500$ in SIPP, $\$ 153,600$ in PSID, and $\$ 237,700$ in the SCF. ${ }^{7}$ Trends in median net worth are also strikingly different in the various surveys: The extreme cases are the SIPP surveys, which document a $17.3 \%$ decline in median net worth between 1984 and 1993, and the PSID waves, which show an 8.3\% increase between 1984 and 1994 !

For the narrow purpose of estimating household wealth there is some consensus that SCF is the best of the surveys and that SIPP is the least reliable (Wolff 2000; Smith 1995, p. S165). The SCF is more detailed in regard to questions about asset holdings and it uses a stratified design, with an oversample of the rich. Since wealth holdings are highly concentrated, a stratified sample will provide better estimates of the holdings of the very wealthy than will a representative design, which is used in the SIPP. Most of the estimates presented in this section of the paper come from calculations by Edward Wolff and by Mishel and his colleagues, which are based on the SCF.

\section{THE TRANSMISSION OF INEQUALITY}

There is a long-standing interest in stratification research in regard to assessing the extent of replication of advantage across generations. Indeed, a defining feature of the status attainment model is the decomposition of the association between father's occupational status and son's status (Blau \& Duncan 1967; Duncan et al 1972). The mechanisms underlying this linkage are presumed to be parental support for educational attainment, peer and family values regarding the importance of education, and, sometimes, parental assistance with occupational entrance, especially when craft union membership is involved. As such, in the attainment model,

\footnotetext{
${ }^{7}$ Some insight into the sources of the differences is provided by Radner (1988). For example, the SIPP survey includes automobile equity in the net worth estimate; SCF does not. SCF includes the cash value of life insurance and equity in an employer-sponsored profit-sharing savings plan, while SCF does not inquire about these matters.
} 
the transmission of status focuses on opportunities made available by parents to their children. There is no presumption of a direct transfer of occupational position because occupations are not formally inherited in a market economy. Similarly, the empirical correlation between father's and son's earnings is not addressed in terms of a transfer of the parental earnings stream.

The situation is different with respect to parental wealth because most kinds of family assets (except for some pension assets) can be transmitted across generations. Because of the growing recognition of household wealth as a determinant of living standards and economic security, much research in recent years has been carried out on the particular role of parental transfers in the replication of advantage. A variety of component issues relate to this topic, concerning the importance of transfers in the buildup of household wealth, the pattern of intergenerational transmission (whether inter vivos gifts or bequests), the parental "motive" in transferring wealth, and the impact of transfers on the behavior of the recipients.

\section{The Volume of Transfers}

This is a surprisingly difficult matter to summarize because the relevant survey questions have been formulated in a variety of ways which have produced different estimates. With respect to inter vivos transfers, information about incidence and dollar amount is usually collected only for families that have exceeded some threshold value of gifts in a defined time interval. Clearly, an estimate of the amount transferred is sensitive to both the threshold value and the length of the time period about which respondents were queried. Estimates of received inheritances are even more sensitive to length of the time interval, since we are addressing here a relatively rare event.

Nevertheless, to cite some figures on the volume of transfers: McGarry \& Schoeni (1995), examining 1992 Health and Retirement Study (HRS) data, report that $13.8 \%$ of adult children obtained parental assistance in excess of $\$ 500$ in the preceding 12 months; the average transfer totaled \$3,061. MacDonald (1989), analyzing 1987 data from the National Survey of Families and Households, found that $16.8 \%$ of respondents received gifts in the past 5 years, mainly from parents, with an average value of approximately $\$ 5,600$. In the same study, a question about inheritances elicited information that $22.3 \%$ of households had received a bequest, with an average value of $\$ 28,000$ for the sum of all inheritances received.

\section{The Contribution of Transfers to Household Wealth}

Estimates of the relative importance of transfers versus life-cycle accumulation range from 20\% (Modigliani 1988) to 80\% (Kotlikoff \& Summers 1981, 1988). The enormity of the range is due to a variety of measurement problems, in part reflecting whether the estimate of the transfer value is calculated from household surveys, from probate records, or from other sources. Also relevant is whether 
the estimate reflects only bequests or includes inter vivos assistance as well [see Modigilani (1988) or Gale \& Scholz (1994) for a review of the issues].

In addition, definitional problems have contributed to the wide range of estimates. Which assets should be credited to parental transfers and which to life-cycle accumulation? Receipt of a \$100,000 gift is clearly a transfer. But suppose the gift was left in a bank account and, some 20 years later, has compounded to $\$ 200,000$. The latter increment to household wealth is often credited to life-cycle accumulation, but it is the case that the addition is entirely a result of the original transfer (Gale \& Scholtz 1994, p. 153). Related issues concern the distinction between parental consumption and intergenerational transfers. College expenditures for a child who lives with parents are usually treated as parental consumption; however, if the child has established a separate household, the same expenditure is considered a transfer (Modigliani 1988).

Clearly, how one categorizes these different expenditures will influence the amount of current household wealth that is attributed to transfers versus life-cycle accumulation. It also seems evident that this issue would be better served by considering explanatory models that provide for direct and indirect transfers-akin to direct and indirect effects in structural equation models - rather than by arguing over essentially arbitrary definitional distinctions. See Kessler \& Masson (1989) for an excellent discussion of these matters.

\section{The Pattern of Transfers}

How much parental wealth is transmitted to children during parental lifetimes and how much is transferred as end-state bequests? Empirical estimates are few: Cox \& Raines (1985) conclude that 60-67\% of transfers are inter vivos; Gale \& Scholz (1994) suggest a figure of $43 \%$. Tax law affects the parental decision, especially the IRS provision that permits gifts of $\$ 10,000$ per year, tax free, to each recipient, since these transfers can be made outside of a donor's $\$ 650,000$ lifetime exemption from gift and estate taxes. There is also evidence that the material needs of children affect the allocation. In the State of Israel, for example, the absence of a rental housing market places pressure on parents to transfer a sizable portion of their assets at a relatively early point in the life course in order to assist newly married children with the purchase of housing (Spilerman 1999).

When there are several adult children, parents must make decisions about the allocation of inter vivos transfers as well as the timing of gifts. Studies consistently show that the incidence and amount of transfers received decline with the age and financial resources of the child and with number of siblings, and increase with parental income and wealth (Cox \& Rank 1992; McGarry \& Schoeni 1997). Net of these effects, there is evidence of larger transfers when grandchildren are present (Schoeni 1997) and reduced amounts when parents are divorced (Altonji et al 1996). Both Cox \& Raines (1985) and Altonji et al (1996) conclude that financially more needy children are apt to receive larger transfers. 


\section{Parental Motives}

Explanations of the transmittal pattern and, indeed, of why parents make transfers rather than consume all their assets have given rise to a small research industry. First, there is evidence that bequests are not simply a result of parental miscalculations of expected lifetimes (unintended transfers), but that parents deliberately accumulate savings in order to leave assets to their children (Gale \& Scholz 1994; Bernheim 1991). Beyond this finding, a variety of presumed motives have been proposed to explain parental calculations, especially when allocations must be divided among several children. These broadly fall under the rubric of altruistic and exchange motives.

Altruism-based transfers presume that the utility function of the donor includes a term for the recipient's welfare, in short, that the well-being of the adult child matters to the parent (Becker 1974; Laitner 1997). A key implication of the altruism model is that the incidence and amount of transfer will be negatively correlated with the child's household income; indeed, a strict formulation asserts that a dollar decline in the child's income, coupled with a dollar increase in parental income, will result in an additional dollar being transferred to the child (Altonji et al 1997, p. 1121). If several offspring are present, the altruism argument suggests that there will be compensating behavior by parents-more resources given to less well off children.

In the exchange model, in contrast, intergenerational transfers serve as payment for services rendered to a parent, such as visits and telephone calls (Hotlz-Eakin \& Smeeding 1994; Cox 1987). Stark \& Falk (1998) argue that in exchange-based transfers the amount will be positively correlated with the child's income, i.e. parents must pay more for the child's time when his/her income is higher. Others (Cox 1987; McGarry \& Schoeni 1997) point out that the parent could purchase fewer hours at the higher price and conclude that the exchange model is consistent with both a positive and a negative correlation.

Distinguishing between the parental motives has implications for the effectiveness of government redistribution policies (Rosenzweig \& Wolpin 1994; Holtz-Eakin \& Smeeding 1994; Laitner 1997). Altruistic motives could make governmental assistance less essential than it appears, since it would partially offset family aid. For example, the parents of an unemployed child might give less help if a generous government benefit is available to unemployed workers (McGarry \& Schoeni 1995, p. S185). However, if private transfers are motivated by exchange considerations, they need not be crowded out by public assistance programs (Cox \& Rank 1992).

The many studies of parental motives have not produced a consensus. The strict altruism model, in which an increase in the child's income of one dollar is offset by an identical reduction in the transfer amount, is invariably rejected in empirical investigations (e.g. Altonji et al 1996; Cox \& Rank 1992). However, there is evidence for weaker formulations of altruism, in which transfers are seen as compensatory, directed to less well off family members, and intended to reduce 
the variance among them in living standards (McGarry \& Schoeni 1997; Altonji et al 1996; Cox \& Raines 1985). Nonetheless, Cox (1987) and Cox \& Rank (1991) conclude that the transfer data are more consistent with exchange motives than with altruism.

This literature is further complicated by the recent introduction of variant models in an attempt to account for the often contradictory empirical findings. These include "warm glow" giving [parents derive satisfaction from the mere fact of assistance (Schoeni 1997)] and "preference shaping" giving [parents aid children with the intent of instilling guilt and, hopefully, repayment in later years in the form of services to the parents (Stark 1995, p. 50)]. Little consideration has been given in the "motive" literature to the possibility that one or the other model may more accurately characterize the behavior of a particular cultural group or a particular wealth category, as an alternative to a single motive being universally true.

The preceding observations refer to inter vivos transfers. Parental motives have also been investigated with regard to bequest decisions. The basic altruism model predicts that bequests will be allocated so as to compensate for income and asset differences among siblings. Tomes (1981) has argued that bequests do, indeed, function in this way, but more recent research (Bernheim et al 1985; Wilhelm 1996) suggests that the bequest data are more consistent with exchange motives. Yet all these assessments are made tenuous by the fact that the majority of estates are divided equally among children (Menchik 1980; Wilhelm 1996). Moreover, we know little about the extent of compensation by parents in their bequest decisions for prior inter vivos transfers.

\section{The Impact of Transfers}

Less work has been done on the behavioral consequences of transfers than on measurement of the sums transmitted or on inferences of parental motives. There is fairly consistent evidence of a correlation in the neighborhood of 0.4 between the incomes of fathers and sons (Solon 1992; Zimmerman 1992). Although these studies do not identify the mechanisms by which income status is transmitted, Holtz-Eakin \& Smeeding (1994, pp. 132-33) suggest that inter vivos transfers for college study constitute one important factor. Consistent with this contention, Rumberger (1983), in an analysis of fathers and sons from the National Longitudinal Survey of Labor Market Experience, reported that parental wealth has an influence on educational attainment that is independent of other background variables.

Aside from parental wealth effects on the human capital of offspring, Holtz-Eakin et al (1993), in an analysis of the household supply of labor, reported a decline with size of inheritance received. In a study of wealth in Israel, Spilerman (1999) documented earlier home purchases and greater home equity when parental assistance was provided; Kennedy \& Stokes (1982) reported similar findings with US data. Finally, there is evidence that even the expectation of a bequest can lower the savings rate of young families (Weil 1994). 


\section{Race and Intergenerational Transfers}

African-Americans have a lower incidence of providing transfers and lesser amounts are involved when a transfer takes place (Smith 1995). An obvious reason is the smaller wealth holdings of African-American families. But it is also the case that, controlling for parental income (Cox \& Rank 1992) and for income and wealth (McGarry 1997; McGarry \& Schoeni 1995), the incidence of receipt of financial aid by African-Americans falls well below the white rate. ${ }^{8} \mathrm{~A}$ possible explanation is that the funds available for transfer are nonlinearly related to parental resources (since there is little asset accumulation in poor households or even in ones moderately above the poverty line), and the usual linear regression misspecifies the relationship, overestimating the transfer volume by low-asset, disproportionately nonwhite parents. The negative coefficient for African-American or nonwhite would then partially offset the misspecification.

One implication of the lesser transfer volume by African-American parents relates to the potentially lower rate of future wealth buildup in this population group. At the beginning of the section it was noted that a sizable portion of current household wealth is attributable to intergenerational transfers, though the precise amount is in dispute. A low rate of asset transmission by African-American families might retard the process of narrowing the racial gap in wealth and living standards. Apropos this observation is the contention by Blau \& Graham (1990) that even if policies intended to reduce racial differences in income and other human capital characteristics were successful, some three-quarters of the wealth gap would remain. They go on to suggest that much of the wealth disparity is attributable to racial differences in inter vivos transfers and in the value of inheritances.

\section{Family Organization and Transfers}

I conclude this section by noting that while I have emphasized stratification issues, the material on intergenerational transfers is equally relevant to an understanding of family structure and interfamily relations. This somewhat different take on the subject matter brings into the discussion a greater concern with exchanges of time, space, backward flows of assistance to elderly parents, and an assessment of how these transactions are played out in different cultures and family contexts. Insights into this perspective on intergenerational relations can be found in Soldo \& Hill (1993), Rossi \& Rossi (1990), Hogan \& Spenser (1993), Attias-Donfut (1995), Attias-Donfut \& Segalen (1998) and Kohli (1999). The last three provide

\footnotetext{
${ }^{8}$ Findings for socio-emotional and instrumental support (assistance with cleaning, shopping, repairs) are less clear with respect to a racial effect. Mutran (1985) reports that AfricanAmerican parents give and receive more support than white parents. Silverstein \& Waite (1993) conclude that the racial assistance patterns are complex and depend on the type of support and on the ages of the provider and recipient. Hogan et al (1993) find that AfricanAmericans are consistently less likely than whites or Mexican-Americans to be involved in any sort of intergenerational assistance.
} 
an excellent overview of many of the themes considered in this paper as they pertain to the French and German context.

\section{SOCIAL POLICY AND STRATIFICATION THEORY}

\section{Policy Considerations}

I wish to discuss two implications for social policy that derive from the preceding review of wealth and its correlates: $(a)$ asset building strategies for low income households, and $(b)$ the role of tax policy in mediating the replication of inequality across generations.

Asset-Building Strategies I have outlined a number of benefits that derive from even modest levels of household wealth, especially as they pertain to economic security, prospects for home ownership, and the possibility of self-employment. Based on a similar appraisal of the contributions of household wealth, Michael Sherraden has drawn several implications for anti-poverty policy.

Sherraden $(1991,2000)$ first points out that the poor are not in a position to participate in the asset building programs available to middle class families, such as IRA accounts, 401(k)s, and home mortgage subsidies. The poor do not benefit because the advantages are provided through the tax structure, in the form of tax credits, and are available only to families that pay income tax. Moreover, antipoverty policy is dominated by an income support philosophy that has the goal of maintaining a minimum consumption level in poor households. There are no incentives for asset building; indeed, most poverty programs are means tested and impose limits on asset ownership, often requiring a needy family to spend down its resources in order to qualify for welfare support.

As a consequence, current poverty policy discourages the buildup of savings by poor households, accentuating a family's vulnerability to economic dislocation were it to leave welfare. The prospects for capital accumulation are inhibited, along with the possibility of purchasing a residence or engaging in entrepreneurial activity - the very sorts of behavior that, ostensibly, we seek to encourage: family stability and investment in the community and in one's future, along with the values of thrift and economic betterment.

Extrapolating from this argument, Sherraden (1991, chap. 10; 2000), together with Oliver \& Shapiro (1995), have outlined a strategy intended to institutionalize asset building by poor households for the targeted purposes of home purchase and income-generating investments. The vehicle would be a program of "individual development accounts" (IDAs)—savings accounts from which monies could be withdrawn only for the designated uses. Participation by the working poor would be encouraged through the provision of matching deposits. For the very poor, who are not able to save from their incomes, deposits would be provided by means of refundable tax credits, akin to the Earned Income Tax Credit. The key to all this is the term "refundable," which would entail government payments when household 
income falls below a threshold level, in contrast to the more standard tax credits, which have value only to higher income households.

This approach would represent a fundamental departure from existing poverty policy. It would supplement, or replace, current income maintenance programs with a new objective of empowering poor persons. They would now have to evaluate alternative expenditures for their monies and calculate the potential risk from different investments, and they would reap the benefits or loss from their decisions. The presumption is that such a program would encourage poor individuals to undertake better economic planning, adopt lengthier time horizons, and develop an increased civic involvement, if only to protect their investments in homes and small businesses (Sherraden 2000). Research to assess the effectiveness of an asset-building strategy is currently being undertaken by the Ford Foundation.

Inheritance and the Tax Code There are many factors involved in the generation of social inequality. Inheritance of wealth, however, invites particular attention because, unlike labor market rewards, it is unrelated to a recipient's efforts or contributions (Britain 1977; Chester 1998; Thurow 1975, p. 197). Moreover, inheritance provides an individual with a clear and obvious lead in life's economic race. This has troubled some who have accumulated great fortunes, as well as several founders of this country. Both Andrew Carnegie ${ }^{9}$ and Thomas Jefferson, for example, felt that society had an interest in regulating, and moderating, the transmission of advantage (Johnson \& Eller 1998; Chester 1982).

The principal means for regulating estate transfers is through the tax code. Nominally, estate taxation is progressive, with marginal rates rising from $37 \%$ to $55 \%$ after an exclusion of $\$ 650,000$ ( $\$ 1.3$ million for a married couple). In practice, there are a great many loopholes in estate taxation, with the effect that, as Thurow $(1975$, p. 197) has written, "for all practical purposes, gift and inheritance taxes do not exist in the United States," while Cooper (1979) has labeled these levies a "voluntary tax." Indeed, in 1985, wealth transfer taxes accounted for less than $1 \%$ of total IRS tax revenues (Wolff 1996, p. 36).

With the massive buildup of family wealth over the past 50 years, much of which is stored in the form of a primary residence and not spent down by the elderly, and with the growing volume of intergenerational transfers as the parental generation departs (Johnston 1999, p. C2), it is likely that the matter of gift and estate taxation will be revisited in public policy debates. Indeed, during the 1996 presidential campaign, Robert Dole proposed that estate taxes be abolished, and the Congressional Republicans' 1999 tax bill included a provision that would have

\footnotetext{
${ }^{9}$ In The Gospel of Wealth Carnegie remarked that "the thoughtful man" must say: "I would as soon leave to my son a curse as the almighty dollar" [Carnegie 1962 (originally 1889), p. 21]. Additionally, commenting on tax policy, he wrote: "The budget presented to the British Parliament the other day proposes to increase the death duties; and, most significant of all, the new tax is to be a graduated one. Of all forms of taxation this seems the wisest" (Carnegie 1962, pp. 21-22).
} 
repealed the estate tax. The recent advocacy of such legislation is surely a result of the growing amount of wealth that is now at stake.

At the same time, reflecting a concern with the replication of wealth inequality across generations, there have been recommendations to revise the tax code and reduce the availability of tax avoidance strategies-e.g. legacy insurance plans, private annuity arrangements, trusts of various kinds - that can effectively reduce the estate tax burden for a wealthy household to near zero. ${ }^{10}$ Spilerman (2000) has suggested that a parallel rate schedule be incorporated into the estate tax code, analogous to the Alternative Minimim Tax in income taxation. Thus, rather than eliminate the existing vehicles for wealth sheltering at the time of estate transfers, the second schedule, with firm minimum rates, would come into play once the sheltering provisions of current tax law are invoked.

Munnell (1988), in a comprehensive review of estate taxation, put forward a more radical plan. Arguing that estate and gift tax law is so deeply permeated with avoidance possibilities that it cannot be effectively repaired, he proposed that these transfer taxes be eliminated in favor of a different arrangement. In their place, Munnell would have the income tax code expanded to include the value of gifts and inheritances in "adjusted gross income" of the recipient in the annual filing of income returns. In short, instead of taxing a deceased's total estate and leaving the bequests received by inheritors untaxed - the current approach in transfer taxation-inheritances would be treated as taxable income in the year received, possibly subject to a lower levy than ordinary income, as is the case with capital gains.

\section{Implications for Stratification Research}

I conclude with some observations about household wealth and stratification processes. As noted in the introduction, a consideration of wealth becomes relevant once the agenda of the field is enlarged, from a focus narrowly on labor market success and its rewards to a concern with living standards and economic securitywhat I have termed consumption potential, i.e. the resource base for ensuring a particular living standard. Income from labor market activity can be then viewed as comprising but one component of this broader measure of economic well-being.

While a consumption perspective has not been at the forefront of theory development in stratification, it has not been entirely absent either. The writings of the British urban sociologists-Forrest \& Murie (1989), Dunleavy (1979), and Saunders $(1984 ; 1986)$ — are pertinent to this matter. Thus, Saunders (1984, p. 217) has argued that consumption sector cleavages, in regard to housing tenure (homeowner

\footnotetext{
${ }^{10} \mathrm{~A}$ different approach to reducing inequality would be to directly tax household wealth by means of an annual net worth tax. A number of European countries have such a provision in their tax code. However, there is no tradition of wealth taxation in this country and there appears to be little public interest in the possibility. For details on wealth taxation, see Wolff (1996) and Thurow (1987).
} 
versus renter), access to quality schooling, and access to health care, are to a considerable degree replacing production-based divisions as the major fault line in social stratification, with implications for the pattern of future social conflict. These cleavages are seen by Saunders as not merely derivative of ones arising from the organization of production, but as cross-cutting the production-based (class) divisions.

Saunders' analysis, and that of the British urban school, remains rooted in the particular theme of housing tenure. He writes about home ownership generating a buildup of household wealth, about the financial security provided by home equity, and about the inheritance of home equity in amounts that often exceed what a working class family could hope to save from its employment earnings (Saunders 1986, pp. 322-24). However, the above assessment readily generalizes to the benefits of most kinds of household assets, and this is reflected in his concluding comments: "As this process unfolds, it will force social scientists to reconsider their nineteenth-century conceptions of class and inequality as simply phenomena of the organization of production" (Saunders 1986, p. 324).

It is not my intention here to discuss the constituents of a proper formulation of economic class and whether or not it should be defined solely on the basis of position in the productive order. This view, however, does appear to be the consensus; even Saunders (1984, p. 206) has repudiated the notion of housing classes, agreeing that "class relations are constituted only through the social organization of production." Rather, my intent is to emphasize the growing awareness of the need to extend stratification theory and analysis to encompass a consideration of a family's total resource base, not just the returns from labor market activity.

In his classic distinction between acquisition classes and property classes, Weber (1947) also gives greater weight to household wealth than applications of his formulation would suggest. The first of his class types has been the more influential in stratification research since it refers to the disposition of marketable skills and, hence, to occupational differentiation. Property classes have received less attention because, as Parkin (1978, p. 608) observed, "the entire weight of class analysis [at the current time] is borne by the consideration of those inequalities stemming from the division of labor." Yet, in Weber's formulation, property class is a more inclusive concept than the Marxian definition of class, in that it is not limited to considerations of ownership of capital goods, but encompasses other kinds of household wealth; indeed, Weber notes that "positively privileged property classes" might live on income from securities (Weber 1947, p. 425), in short, on wealth assets external to the labor market.

Weber's evocative concept of "life chances" is also based on a broader view of opportunity and economic well-being than is subsumed under occupational rewards. Although he defines life chances variously [see Dahrendorf (1979, pp. 6274) for an account of Weber's use of this term], it consistently relates to the "chance for a supply of goods [and] external living conditions" (Weber 1958, p. 181), that is, to the fundamental aspects of a household's future possibilities. This formulation, clearly, concerns the totality of marketable resources available to a household. 
There have been a few attempts to expand the formulation of economic status by incorporating considerations of net worth and transfers of wealth into an attainment model. Prominent among these are Henretta \& Campbell $(1978 ; 1980)$ and Rumberger (1983). Possibly these impressive papers from some 20 years ago failed to stimulate a new line of work because few data on household wealth were available at the time; possibly they were too far ahead of the established paradigms in stratification research to be appreciated. Whatever the reason, the result can be seen from this review: The great majority of the cited papers on wealth issues come from studies carried out by economists, not sociologists.

Yet recent trends should bring a consideration of wealth issues to the fore. These include the buildup of household wealth in the American population, the intergenerational transfer of sums that are substantial for an average family, and pronounced shifts in wealth inequality - trends that cannot be ignored in a discipline that places living standards and economic well-being at the core of its domain. The conceptual approach to incorporating wealth variables is not complex, though the proper formulation of the wealth measure, especially in assessments of its impact on some behavioral outcome, is not obvious. At a minimum, this will require a consideration of which components of a household's asset holdings to include, whether to combine income and wealth into a single resource measure, and how to incorporate parental resources which a respondent expects to receive in the future but which may influence his or her current behavior.

\section{ACKNOWLEDGMENTS}

The author wishes to thank Michael Sobel and Yuval Elmelech for their helpful comments.

\section{Visit the Annual Reviews home page at www.AnnualReviews.org}

\section{LITERATURE CITED}

Alessie R, Lusardi A, Aldershof T. 1997. Income and wealth over the life cycle: evidence from panel data. Rev. Income Wealth 43:1-32

Altonji JG, Hayashi F, Kotlikoff LJ. 1997. Parental altruism and inter vivos transfers: theory and evidence. J. Polit. Econ. 105:1121-66

Altonji JG, Hayashi F, Kotlikoff LJ. 1996. The effects of income and wealth on time and money transfers between parents and children. Natl. Bur. Econ. Res. Working paper 5522. Unpublished

Attias-Donfut C. 1995. Les Solidarités Entre
Generations: Vieillesse, Familles Etat. Paris: Nathan

Attias-Donfut C, Segalen M. 1998. GrandsParents: La Famille a Travers les Generations. Paris: Odile Jacob

Baltzell ED. 1958. Philadelphia Gentleman: The Making of a National Upper Class. New York: Free Press

Barber B. 1975. Social Stratification. New York: Harcourt, Brace and World

Becker G. 1974. A theory of social interactions. J. Polit. Econ. 82:1045-76

Bernheim B, Douglas AS, Summers LH. 1985. 
The strategic bequest motive. J. Polit. Econ. 93:1045-76

Bernheim D. 1991. How strong are bequest motives? Evidence based on estimates of the demand for life insurance and annuities. J. Polit. Econ. 99:899-927

Blau FD, Graham J. 1990. Black-white differences in wealth and asset compositon. $Q . J$. Econ. 105:321-40

Blau P, Duncan OD. 1967. The American Occupational Structure. New York: John Wiley

Brittain JA. 1977. The Inheritance of Economic Status. Washington, DC: Brookings Inst.

Burkhauser RV, Weathers R. 2000. Access to wealth among the new-old and how it is distributed: data from the health and retirement study. In The Benefits and Mechanisms for Spreading Asset Ownership, ed. T Shapiro, EN Wolff. New York: Russell Sage. In press

Carnegie A. 1962. The gospel of wealth. In The Gospel of Wealth and other Timely Essays. ed. EC Kirkland, pp. 14-49. Cambridge, MA: Harvard Univ. Press

Chester R. 1982. Inheritance, Wealth and Society. Bloomington: Univ. Indiana Press

Chester R. 1998. Inheritance in American legal thought. In Inheritance and Wealth in America, ed. RK Miller Jr, SJ McNamee, pp. 2344. New York: Plenum Press

Committee on Ways and Means. 1992. Overview of Entitlement Programs (1992 Green Book). US House of Rep. Washington, DC: Gov. Print. Office

Conley D. 1999. Being Black, Living in the Red: Race, Wealth, and Social Policy in America. Berkeley: Univ. Calif. Press

Conley D, Spilerman S. 1999. Capital for college: parental assets and educational attainment. Dept. of Sociol., Yale Univ. Unpubl. paper

Cooper G. 1979. A Voluntary Tax? New Perspectives on Sophisticated Tax Avoidance. Washington, DC: Brookings Inst.

Cox D. 1987. Motives for private income transfers. J. Polit. Econ. 95:508-46

Cox D, Raines F. 1985. Interfamily transfers and income redistribution. In Horizontal Eq- uity, Uncertainty, and Economic Well-Being, ed. M David, T Smeeding, pp. 393-425. Chicago: Univ. Chicago Press

Cox D, Rank MR. 1992. Inter-vivos transfers and intergenerational exchange. Rev. Econ. and Stat. 74:305-14

Current Population Reports. 1986. Household Wealth and Asset Ownership. Household Economic Studies P-70(7). US Dept. of Commerce. Washington, DC: Gov. Print. Office

Dahrendorf R. 1979. Life Chances. Chicago: Univ. Chicago Press

Danziger S, Haveman R, Plotnick R. 1991. How income tranfers affect work, savings, and the income distribution. J. Econ. Literature 19:975-1028

Davis K, Moore WE. 1945. Some principles of stratification. Am. Sociol. Rev. 10:242-49

Duncan OD, Featherman D, Duncan B. 1972. Socioeconomic Background and Achievement. New York: Seminar Press

Dunleavy P. 1979. The urban basis for political alignment: social class, domestic property ownership, and state intervention in consumption processes. Br. J. Polit. Sci. 9:40943

Feinstein J, McFadden D. 1987. The dynamics of housing demand by the elderly: wealth, cash flow, and demographic effects. Natl. Bur. Econ. Res. Working paper 2471. Unpublished

Forrest R, Murie A. 1989. Differential accumulation: wealth, inheritance and housing policy reconsidered. Policy Polit. 17:25-39

Gale WG, Scholz JK. 1994. Intergenerational transfers and the accumulation of wealth. $J$. Econ. Perspect. 8:145-60

Giddens A. 1973. The Class Struture of the Advanced Societies. New York: Harper \& Row

Henretta JC, Campbell RT. 1978. Net worth as an aspect of status. Am. J. Sociol. 83:1204-23

Henretta JC, Campbell RT. 1980. Status claims and status attainment: the determinants of financial well-being. Am. J. Sociol. 86:618-29

Hogan DP, Eggebeen DJ, Clogg CC. 1993. The structure of intergenerational exchanges in 
American families. Am. J. Sociol. 98:142858

Hogan DP, Spenser LJ. 1993. Kin structure and assistance in aging societies. In Annual Review of Gerontology and Geriatrics, ed. GL Maddox, MP Lawton. New York: Springer

Holtz-Eakin D, Joulfaian D, Rosen HS. 1993. The Carnegie conjecture: some empirical evidence. Q. J. Econ. 63:413-36

Holtz-Eakin D, Smeeding TM. 1994. Income, wealth, and intergenerational economic relations of the aged. In Demography of Aging, ed. LG Martin, SH Preston. Washington, DC: National Academy Press

Jencks C. 1979. Who Gets Ahead: The Determinants of Economic Success in America. New York: Basic Books

Jencks C, Smith M, Acland H, Bane MJ, Cohen D, Gintis H, et al 1972. Inequality. New York: Basic Books

Johnson BW, Eller MB. 1998. Federal taxation of inheritance and wealth transfers. In Inheritance and Wealth in America, ed. RK Miller Jr, SJ McNamee, pp. 61-90. New York: Plenum Press

Johnston DC. 1999. A larger legacy may await generations X, Y, and Z. New York Times, Oct. 20:C2

Kennedy LW, Stokes DW. 1982. Extended family support and the high cost of housing. $J$. Marriage Fam. 44:311-18

Kessler D, Masson A. 1989. Bequest and wealth accumulation: Are some pieces of the puzzle missing? J. Econ. Perspect. 3:141-52

Kohli M. 1999. Private and public transfers between generations: linking the family and the state. Eur. Soc. 1:81-104

Kolko G. 1962. Wealth and Power in America: An Analysis of Social Class and Income Distribution. New York: Praeger

Kotlikoff LJ, Summers LH. 1981. The role of intergenerational transfers in aggregate capital accumulation. J. Polit. Econ. 89:706-32

Kotlikoff LJ, Summers LH. 1988. The contribution of intergenerational transfers to total wealth: a reply. In Modelling the Accumulation and Distribution of Wealth, ed.
D Kessler, A Masson, pp. 53-67. Oxford, UK: Clarendon Press

Laitner J. 1997. Intergenerational and interhousehold economic links. In Handbook of Population and Family Economics, ed. M Rosenzweig, O Stark, pp. 190-237. New York: Elsevier

Lenski G. 1984. Income stratification in the United States: toward a revised model of the system. Res. Soc. Stratification Mobility 3:175-205

Levy F, Michel RC. 1991. The Economic Future of American Families. Washington, DC: Urban Inst. Press

Lindh T, Ohlsson H. 1998. Self-employment and wealth inequality. Rev. Income Wealth 44:25-42

Lipset SM, Zetterberg HL. 1956. A theory of social mobility. Trans. 3rd World Congr. Sociol. 5:155-77

MacDonald MM. 1989. Family background, the life cycle and inter-household transfers. NSFH working paper 13. Center for Demogr. Ecol. Univ. Wisconsin. Unpublished paper

McGarry K. 1997. Intervivos transfers and intended bequests. Natl. Bur. Econ. Res. Work. pap. 6345. Unpublished

McGarry K, Schoeni R. 1995. Transfer behavior in the health and retirement study. J. Hum. Resourc. (Supplement) 30:S184-225

McGarry K, Schoeni R. 1997. Transfer behavior within the family: results from the asset and health dynamics study. J. Gerontol. 52B:82-92

Menchik P. 1979. Intergenerational transmission of inequality: an empirical study of wealth mobility. Economica 46:349-62

Menchik P. 1980. Primogeniture, equal sharing, and the US distribution of wealth. Q.J. Econ. 94:299-316

Mills CW. 1956. The Power Elite. New York: Oxford Univ. Press

Mishel L, Bernstein J, Schmitt J. 1999. The State of Working America. Ithaca, NY: ILR Press

Modigliani F. 1988. Measuring the contribution of intergenerational transfers to total wealth. 
In Modelling the Accumulation and Distribution of Wealth, ed. D Kessler, A Masson, pp. 21-52. Oxford: Clarendon Press

Munnell AH. 1988. Wealth transfer taxation: the relative role for estate and income taxes. N. Engl. Econ. Rev. (Nov./Dec.), pp. 3-28

Mutran E. 1985. Intergenerational family support among blacks and whites: response to culture or to socioeconomic differences. $J$. Gerontol. 40:382-89

Oliver ML, Shapiro TM. 1995. Black Wealth/White Wealth. New York: Routledge

Osberg L. 1984. Economic Inequality in the United States. Armonk, NY: Sharpe

Parkin F. 1971. Class Inequality and Political Order. New York: Praeger

Parkin F. 1978. Social stratification. In A History of Sociological Analysis, ed. T Bottomore, pp. 599-632. New York: Basic Books

Poulantzas N. 1975. Classes in Contemporary Capitalism. London: New Left Books

Projector D, Weiss GS. 1966. Survey of financial characteristics of consumers. Federal Reserve Tech. Paper. Washington, DC: Board of Governors of the Federal Reserve System

Radner DB. 1988. The wealth of the aged and non-aged, 1984. Bureau of the Census. Survey of Income and Program Participation, Paper 8807. Unpublished

Rainwater L, Rein M, Schwartz J. 1986. Income Packaging in the Welfare State: A Comparative Study of Family Income. Oxford: Clarendon Press

Ratcliff RE, Maurer S. 1995. Savings and investment among the wealthy: the uses of assets by high-income families in 1950 and 1983. In Research in Politics and Society: The Politics of Wealth and Inequality (5), ed. G Moore, JA Whitt, RE Ratcliff, ML Oliver, T Shapiro, pp. 99-125. Greenwich, CT: JAI Press

Rosenfeld RA, Kalleberg AL. 1990. A crossnational comparison of the gender gap in income. Am. J. Sociol. 96:69-106

Rosenzweig MR, Wolpin KI. 1994. Parental and public transfers to young women and their children. Am. Econ. Rev. 84:1195-212
Rossi AS, Rossi PH. 1990. Of Human Bonding. New York: Aldine

Rumberger RW. 1983. The influence of family background on education, earnings, and wealth. Soc. Forces 61:755-73

Saunders P. 1978. Domestic property and social class. Int. J. Urban Regional Res. 2: 233-51

Saunders P. 1984. Beyond housing classes. Int. J. Urban Regional Res. 8:202-27

Saunders P. 1986. Social Theory and the Urban Question. London: Hutchinson

Schoeni RF. 1997. Private interhousehold transfers of money and time: new empirical evidence. Rev. Income Wealth 43:423-48

Semyonov M, Lewin-Epstein N, Spilerman S. 1996. The material possessions of Israeli ethnic groups. Eur. Sociol. Rev. 12:289-301

Sherraden M. 1991. Assets and the Poor: A New American Welfare Policy. Armonk, NY: Sharpe

Sherraden M. 2000. Asset building in community development and public policy. In The Benefits and Mechanisms for Spreading Asset Ownership, ed. T Shapiro, EN Wolff. In press

Shorrocks AF. 1987. UK wealth distribution: current evidence and future prospects. In International Comparisons of the Distribution of Household Wealth, ed. EN Wolff. Oxford: Clarendon Press

Silverstein M, Waite LJ. 1993. Are Blacks more likely than Whites to receive and provide support in middle and old age? Yes, No, and maybe so. J. Gerontol. 48:s212-22

Slemrod J. 1991. Taxation and inequality: a time exposure perspective. Presented at the NBER Conf. Tax Policy and the Economy, Nov. 19

Smith JP. 1995. Racial and ethnic differences in wealth in the health and retirement study. $J$. Hum. Resourc. 30 (Suppl.):S159-83

Soldo BJ, Hill MS. 1993. Intergenerational transfers: economic, demographic, and social pespectives. In Annual Review of Gerontology and Geriatrics, ed. GL Maddox, MP Lawton. New York: Springer 
Solon GR. 1992. Intergenerational income mobility in the United States. Am. Econ. Rev. 82:393-408

Spant R. 1987. Wealth distribution in Sweden: 1920-1983. In International Comparisons of the Distribution of Household Wealth, ed. EN Wolff. Oxford: Clarendon Press

Spilerman S. 1999. Home ownership, intergenerational assistance, and wealth inequality in Israel. Dept. Sociol., Columbia Univ., New York. Unpublished

Spilerman S. 2000. Some observations on asset ownership, living standards, and poor families. In The Benefits and Mechanisms for Spreading Asset Ownership, ed. T Shapiro, EN Wolff. In press

Spilerman S, Lewin-Epstein N, Semyonov M. 1993. Wealth, intergenerational transfers, and life chances. In Social Theory and Social Policy, ed. A Sorensen, S Spilerman. New York: Praeger

Stark O. 1995. Altruism and Beyond. Cambridge, UK: Cambridge Univ. Press

Stark O, Falk I. 1998. Transfers, empathy formation, and reverse transfers. AEA Papers Proc. 88:271-76

Theeuwes J. 1981. Family labor force participation: multinomial logit estimates. Appl. Econ. 13:481-98

Thurow LC. 1975. Generating Inequality. New York: Basic Books

Thurow LC. 1987. Tax wealth, not income. In Structured Social Inequality, ed. CS Heller, pp. 145-50. New York: Macmillan

Tomes N. 1981. The family, inheritance, and the intergenerational transmission of inequality. J. Polit. Econ. 89:925-58

Weber M. 1947. Social stratification and class structure. In Max Weber: The Theory of Social and Economic Organization, ed. T Parsons. New York: Free Press

Weber M. 1958. Class, status, party. In From Max Weber, ed. HH Gerth, CW Mills. New York: Oxford Univ. Press

Weil DN. 1994. The savings of the the elderly in micro and macro data. Q. J. Econ. 109:55-81
Wilcox D. 1991. Household spending and saving: measurement, trends, and analysis. Federal Reserve Bull. (Jan.):

Wilhelm MO. 1996. Bequest behavior and the effect of heirs' earnings: testing the altruistic model of bequests. Am. Econ. Rev. 86:87492

Wolff EN. 1980. Estimates of the 1969 size distribution of household wealth in the US from a synthetic data base. In Modeling the Distribution and Intergenerational Transmission of Wealth, ed. JD Smith. Chicago: Univ. Chicago Press

Wolff EN. 1987. Estimates of household wealth inequality in the US, 1962-83. Rev. Income Wealth 33:231-42

Wolff EN. 1989. Trends in aggregate household wealth in the US, 1900-83. Rev. Income Wealth 34:1-29

Wolff EN. 1990. Wealth holdings and poverty status in the US. Rev. Income Wealth. 36:14365

Wolff EN. 1994. Trends in household wealth in the United States, 1962-83 and 1983-89. Rev. Income Wealth 40:143-74

Wolff EN. 1995. The rich get increasingly richer: latest data on household wealth during the 1980s. In Research in Politics and Society: The Politics of Wealth and Inequality (5), ed. G Moore, JA Whitt, RE Ratcliff, ML Oliver, T Shapiro. Greenwich, CT: JAI Press

Wolff EN. 1996. Top Heavy. New York: New Press

Wolff EN. 2000. Recent trends in wealth ownership. In The Benefits and Mechanisms for Spreading Asset Ownership, ed. T Shapiro, EN Wolff. In press

Wright EO. 1985. Classes. London: New Left Books

Wright EO, Perrone L. 1977. Marxist class categories and income inequality. Am. Sociol. Rev. 42:32-55

Zimmerman DJ. 1992. Regression toward mediocrity in economic stature. Am. Econ. Rev. 82:409-29 


\section{CONTENTS}

COHABITATION IN THE UNITED STATES: An Appraisal of

Research Themes, Findings, and Implications, Pamela J. Smock

DOUBLE STANDARDS FOR COMPETENCE: Theory and Research,

Martha Foschi

THE CHANGING NATURE OF DEATH PENALTY DEBATES,

Michael L. Radelet, Marian J. Borg

WEALTH INEQUALITY IN THE UNITED STATES, Lisa A. Keister,

Stephanie Moller

CRIME AND DEMOGRAPHY: Multiple Linkages, Reciprocal Relations,

Scott J. South, Steven F. Messner

ETHNICITY AND SEXUALITY, Joane Nagel

PREJUDICE, POLITICS, AND PUBLIC OPINION: Understanding the

Sources of Racial Policy Attitudes, Maria Krysan

135

RACE AND RACE THEORY, Howard Winant

STATES AND MARKETS IN AN ERA OF GLOBALIZATION, Seán

Ó Riain

VOLUNTEERING, John Wilson

HOW WELFARE REFORM IS AFFECTING WOMEN"S WORK, Mary

Corcoran, Sandra K. Danziger, Ariel Kalil, Kristin S. Seefeldt

FERTILITY AND WOMEN"S EMPLOYMENT IN INDUSTRIALIZED

NATIONS, Karin L. Brewster, Ronald R. Rindfuss

POLITICAL SOCIOLOGICAL MODELS OF THE U.S. NEW DEAL,

Jeff Manza

THE TREND IN BETWEEN-NATION INCOME INEQUALITY, Glenn

Firebaugh

NONSTANDARD EMPLOYMENT RELATIONS: Part-time, Temporary and Contract Work, Arne L. Kalleberg

SOCIAL PSYCHOLOGY OF IDENTITIES, Judith A. Howard

SCHOOLS AND COMMUNITIES: Ecological and Institutional

Dimensions, Richard Arum

395

RACIAL AND ETHNIC VARIATIONS IN GENDER-RELATED

ATTITUDES, Emily W. Kane

419

MULTILEVEL MODELING FOR BINARY DATA, Guang Guo,

Hongxin Zhao

441

A SPACE FOR PLACE IN SOCIOLOGY, Thomas F. Gieryn

463

WEALTH AND STRATIFICATION PROCESSES, Seymour Spilerman

497

THE CHOICE-WITHIN-CONSTRAINTS NEW INSTITUTIONALISM

AND IMPLICATIONS FOR SOCIOLOGY, Paul Ingram, Karen Clay

POVERTY RESEARCH AND POLICY FOR THE POST-WELFARE

ERA, Alice O'Connor

CLOSING THE "'GREAT DIVIDE"': New Social Theory on Society

and Nature, Michael Goldman, Rachel A. Schurman

SOCIALISM AND THE TRANSITION IN EAST AND CENTRAL

EUROPE: The Homogeneity Paradigm, Class, and Economic , Linda

Fuller 
FRAMING PROCESSES AND SOCIAL MOVEMENTS: An Overview and Assessment, Robert D. Benford, David A. Snow

FEMINIST STATE THEORY: Applications to Jurisprudence,

Criminology, and the Welfare State, Lynne A. Haney

641

PATHWAYS TO ADULTHOOD IN CHANGING SOCIETIES:

Variability and Mechanisms in Life Course Perspective, Michael J.

Shanahan

667

A SOCIOLOGY FOR THE SECOND GREAT TRANSFORMATION, Michael Burawoy

693

AGENDA FOR SOCIOLOGY AT THE START OF THE TWENTY-

FIRST CENTURY, Michael Hechter

697

WHAT I DON'T KNOW ABOUT MY FIELD BUT WISH I DID,

Douglas S. Massey

699

FAMILY, STATE, AND CHILD WELL-BEING, Sara McLanahan

703

GETTING IT RIGHT: SEX AND RACE INEQUALITY IN WORK

ORGANIZATIONS, Barbara F. Reskin

707

WHITHER THE SOCIOLOGICAL STUDY OF CRIME, Robert J.

Sampson

711

ON GRANULARITY, Emanuel Schegloff

715

HOW DO RELATIONS STORE HISTORIES?, Charles Tilly 